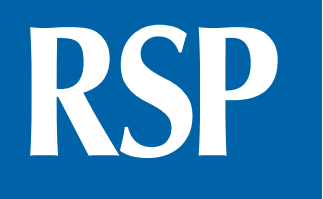

http://www.rsp.fsp.usp.br/
Revista de Saúde Pública

\title{
Effects of air pollution caused by sugarcane burning in Western São Paulo on the cardiovascular system
}

\author{
Paula Roberta da Silva Pestana ${ }^{1, \text { II }}$, Alfésio Luís Ferreira Braga ${ }^{\mathrm{II}, \mathrm{II}}$, Ercy Mara Cipulo Ramos', Ariadna \\ Ferraz de Oliveira" ${ }^{I I I}$, Christian Robert Osadnik ${ }^{\mathrm{V} V \mathrm{VI}, \mathrm{VII}}$, Aline Duarte Ferreiraa ${ }^{\mathrm{I}, \mathrm{II}, \mathrm{IV}}$, Dionei Ramos ${ }^{1}$ \\ I Departamento de Fisioterapia. Faculdade de Ciências e Tecnologia. Universidade Estadual Paulista Júlio de \\ Mesquita Filho. Presidente Prudente, SP, Brasil \\ " Departamento de Patologia. Núcleo de Estudos em Epidemiologia Ambiental. Laboratório de Poluição \\ Atmosférica Experimental. Faculdade de Medicina. Universidade de São Paulo. São Paulo, SP, Brasil \\ III Programa de Pós-Graduação em Saúde Coletiva. Universidade Católica de Santos. Santos, SP, Brasil \\ Iv Departamento de Fisioterapia e Educação Física. Universidade do Oeste Paulista. Presidente Prudente, SP, Brasil \\ $\checkmark$ Department of Rehabilitation Sciences. Katholieke Universiteit Leuven. Leuven, Belgium \\ v' Department of Physiotherapy. Monash University. Frankston, Victoria, Australia \\ VII Institute for Breathing and Sleep. Heidelberg, Australia
}

Correspondence:

Paula Roberta da Silva Pestana Rua Adelino Belonci, 151

19085-210 Presidente Prudente

SP, Brasil

E-mail: paularspestana@hotmail.com

Received: 23 Jun 2015

Approved: 14 Nov 2015

How to cite: Pestana PRS, Braga ALF, Ramos EMC, Oliveira AF, Osadnik CR, Ferreira AD, et al. Effects of air pollution caused by sugarcane burning in Western São Paulo on the cardiovascular system. Rev Saude Publica. 2017;51:13.

Copyright: This is an open-access article distributed under the terms of the Creative Commons Attribution License, which permits unrestricted use, distribution, and reproduction in any medium, provided that the original author and source are credited.

\section{ABSTRACT}

OBJECTIVE: To evaluate the effects of acute exposure to air pollutants $\left(\mathrm{NO}_{2}\right.$ and $\left.\mathrm{PM}_{10}\right)$ on hospitalization of adults and older people with cardiovascular diseases in Western São Paulo.

METHODS: Daily cardiovascular-related hospitalization data (CID10 - I00 to I99) were acquired by the Department of Informatics of the Brazilian Unified Health System (DATASUS) from January 2009 to December 2012. Daily levels of $\mathrm{NO}_{2}$ and $\mathrm{PM}_{10}$ and weather data were obtained from Companhia Ambiental do Estado de São Paulo (CETESB - São Paulo State Environmental Agency). To estimate the effects of air pollutants exposure on hospital admissions, generalized linear Poisson regression models were used.

RESULTS: During the study period, 6,363 hospitalizations were analysed. On the day of $\mathrm{NO}_{2}$ exposure, an increase of $1.12 \%$ (95\% CI $0.05-2.20)$ was observed in the interquartile range along with an increase in hospital admissions. For $\mathrm{PM}_{10}$, a pattern of similar effect was observed; however, results were not statistically significant.

CONCLUSIONS: Even though with values within established limits, $\mathrm{NO}_{2}$ is an important short-term risk factor for cardiovascular morbidity.

DESCRIPTORS: Nitrogen Dioxide, adverse effects. Air Pollution, adverse effects. Agricultural Cultivation. Fires. Cardiovascular Diseases. 


\section{INTRODUCTION}

Human exposure to air pollutants from anthropogenic sources is a public health problem and contributes to increased morbidity due to cardiovascular disease ${ }^{3,9}$. Primary pollutants, such as particulate matter $\left(\mathrm{PM}_{10}\right.$ and $\left.\mathrm{PM}_{2,5}\right)$, sulfur dioxide $\left(\mathrm{SO}_{2}\right)$, nitrogen dioxide $\left(\mathrm{NO}_{2}\right)$ and carbon monoxide (CO), have been shown to have significant negative effects on the cardiovascular system. They are also known triggers for a range of cardiovascular-related conditions such as angina pectoris, acute myocardial infarction, thromboembolic complications, arrhythmias, and decompensated congestive cardiac failure ${ }^{18}$. Therefore, it is reasonable to hypothesize that sustained exposure to air pollutants may relate to the incidence of hospitalization for cardiovascular-related conditions.

This rationale is supported by evidence of association between raised air $\mathrm{NO}_{2}$ levels and the development of cardiovascular disease ${ }^{21}$ and significant increases in the risk of hospitalization due to myocardial infarction (mean increase of $12.7 \%$ [95\%CI 5.8-18) ${ }^{14}$. Data also exist from large ( $\mathrm{n}>400,000$ people) international datasets ${ }^{23}$; however, extrapolation of findings beyond the region of the original investigations can be difficult. For example, differences in air pollution matter can occur between metropolitan and rural regions, while differences in source space-time variability can occur between similar metropolitan regions of different geographical regions. Importantly, regional exposure to air pollutants, even in the short-term or in response to low concentrations, is strongly associated with poor health outcomes $^{22}$. Climatic factors, such as thermal temperature, may amplify this response, since hotter weather has been considered a causative factor for increased cardiovascular-related hospitalization episodes in developed ${ }^{12,20}$ and developing countries ${ }^{2}$.

São Paulo city is a well-known, densely populated metropolis of Brazil and a major center for a wide range of industries. Its heavy reliance upon significant vehicular fleet predisposes it to be a region of dense air pollution, posing potential health risks to the general community and those who may be susceptible to the effects of air pollutant exposure such as those with cardiovascular disease ${ }^{19}$. The Western region of São Paulo state, however, has unique occupational and environmental concerns, since it is the center of a major sugar mill industry, estimated to produce and harvest approximately $60.0 \%$ of the nation's total sugarcane 8 . A major public health concern associated with this industry is the necessity for plantation burning, conducted to increase productivity and safety of sugarcane cutters. This phase is associated with a rapid surge in release of particulate matter and toxic gases into the environment of regions where sugarcane is planted, harvested, and industrialized.

Potential health issues related to this exposure may be far-reaching from these plantation sites. For example, traces of matter have been shown to travel (via direct and indirect means) to places as far as Presidente Prudente, $\mathrm{SP}^{2,5}$. Such far-reaching effects of excessive $\mathrm{PM}_{10}$ levels and their associated negative impact on cardiovascular health have been observed in other parts of South America, with a recent study from Mexico showing detection of air pollution as far as a $500 \mathrm{~km}$ radius of the original source ${ }^{4}$.

It is of high importance that the relationship between local exposure to air pollutants and cardiovascular-related health outcomes is further elucidated, particularly in developing countries, such as Brazil, and regions such as Western São Paulo, where the likelihood of adverse health effects may be increased. The purpose of this study was to determine the relationship between acute exposure to air pollution $\left(\mathrm{NO}_{2}\right.$ and $\left.\mathrm{PM}_{10}\right)$ and hospitalization of adults and older adults with cardiovascular diseases residing in Western São Paulo, Brazil.

a Instituto Brasileiro de Geografia e Estatística. 2010 Population Census. Rio de Janeiro: IBGE; 2011 [cited 2016 Nov 11]. Available from: http://www. ibge.gov.br/english/estatistica/ populacao/censo2010/

\section{METHODS}

This is an ecological time-series study in the city of Presidente Prudente, Western São Paulo (latitude $22^{\circ} 07^{\prime} 32^{\prime \prime S}$ longitude $51^{\circ} 23^{\prime} 20^{\prime \prime} \mathrm{W}$ ). Presidente Prudente is situated 587 kilometers from the capital city, and occupies a total area of $562 \mathrm{~km}^{2}$. Its population of 220,600 inhabitants makes it the 34th biggest city in São Paulo state, according to IBGE ${ }^{a}$. 
Daily data of adults and older adults' (19 years of age or older) hospitalizations due to cardiovascular diseases (International Classification of Diseases - ICD, 10th revision I00 to I99) in hospitals of the Brazilian Unified Health System (SUS) were obtained from January 2009 to December 2012. Data were included in the study if hospitalizations occurred with residents of Presidente Prudente. Daily concentrations of air pollutants particulate matter $\left(\mathrm{PM}_{10}\right)$ and nitrogen dioxide $\left(\mathrm{NO}_{2}\right)$, and daily values of temperature, relative humidity, precipitation, and wind speed were obtained from Companhia Ambiental do Estado de São Paulo (CETESB - São Paulo State Environmental Agency). Since data can only be collected from one monitoring station, located in the city (in the campus of Faculdade de Ciências e Tecnologia - UNESP), measurements of air pollutants and weather were considered representative of the whole city for the purpose of this study.

Descriptive analyses were carried out for all variables in the study. Correlations between pollutants and meteorological variables were estimated using Pearson's or Spearman's correlation coefficients. The effect of pollutant exposure on cardiovascular hospitalizations was determined via generalized linear Poisson regression models, in which the daily number of cardiovascular hospitalizations was considered the dependent variable, and daily mean levels of each pollutant concentration $\left(\mathrm{PM}_{10}\right.$ and $\left.\mathrm{NO}_{2}\right)$, the independent variables. Seasonality was controlled using natural cubic splines to account for the nonlinear dependence of the dependent variable on time (days) and to exclude the basic seasonal pattern from data. We used 16 degrees of freedom to smooth the time trend minimizing both the autocorrelation between the residuals and the Akaike Information Criterion ${ }^{11}$. After adjusting for the time trend, no remaining serial correlation was found in the residuals, and therefore the use of autoregressive terms was unnecessary. Indicators for day of the week were included to control short-term trends. Since temperature in Presidente Prudente is usually high throughout the year, linear terms for temperature and relative humidity were adopted. To reduce sensitivity to outliers in the dependent variable, robust regression (M-estimation) was used. The lag structure of $\mathrm{PM}_{10}$ and $\mathrm{NO}_{2}$ effects on cardiovascular hospital admissions from the same day to six days before admission was tested using a third degree polynomial distributed lag model ${ }^{5}$. This approach imposes constraints, but provides enough flexibility to estimate a biologically plausible lag structure controlling for multicollinearity that is better than an unconstrained lag model. Standard errors of the estimates for each day were adjusted for overdispersion.

Effects of air pollutants were expressed as a percent increase and 95\% confidence intervals in cardiovascular-related hospitalizations interquartile range (the variation between the $75.0 \%$ higher and the $25.0 \%$ lower daily concentrations) increases in pollutants concentrations. All data were prepared using Statistical Package for Social Science (SPSS) program for Windows, version 17.0. Analyses were performed via S-PLUS 2000 program for Windows. The Project was approved by the Research Ethics Committee of Faculdade de Ciências e Tecnologia (UNESP), Presidente Prudente campus, São Paulo, Brazil (Protocol 51922).

\section{RESULTS}

Table summarises the descriptive analyses of all variables included in the study. Throughout the study period, a total of 6,363 hospitalizations were recorded and attributed as being caused by a cardiovascular condition. Almost half of these hospitalizations, comprising 2,846 cases (44.7\%), were related to people aged 20 to 60, while 3,561 (55.3\%) were from individuals aged above 60 years. The mean number of hospitalizations per day attributable to cardiovascular diseases increased over time during the study period. From 2009 to 2012, these numbers were $0.55(\mathrm{SD}=0.4), 0.58(\mathrm{SD}=0.5), 0.60(\mathrm{SD}=0.5)$ and $0.59(\mathrm{SD}=0.5)$, respectively.

On average, the recorded levels of air pollutants $\mathrm{PM}_{10}$ and $\mathrm{NO}_{2}$ remained within the acceptable limits of air quality according to the World Health Organization (WHO) on most observation days. Daily levels of $\mathrm{PM}_{10}$ second $\mathrm{WHO}$ recommended levels $\left(50 \mu \mathrm{g} / \mathrm{m}^{3}\right)$ on any 
days remaining on average at $64.25 \mu \mathrm{g} / \mathrm{m}^{3}$. Daily levels of $\mathrm{PM}_{10}$ were not significantly related to cardiovascular-related hospitalizations (Figure 1).

The average temperature and relative humidity were related to hospitalizations and air pollutants $\left(\mathrm{NO}_{2}\right.$ and $\left.\mathrm{PM}_{10}\right)$, but were not significant during the study period.

For $\mathrm{NO}_{2}$, the WHO recommended acceptable daily limit $\left(100 \mu \mathrm{g} / \mathrm{m}^{3}\right)$ was exceeded after 37 days, with an average level of $113.11 \mu \mathrm{g} / \mathrm{m}^{3}$ during the study period. Levels $\mathrm{of}^{\mathrm{NO}_{2}}$ were statistically significantly associated with increased risk of hospitalization due to cardiovascular disease, but only on the day that excessively raised $\mathrm{NO}_{2}$ levels were detected (lag 0d) (percent increase of $1.12 \%$ [95\%CI 0.05-2.20]). This significant, short-term effect was of a small magnitude, and tended to reduce over the subsequent six days (to lag 6d). This positive relationship and trend over time was observed in both the younger adult group (20-60 years) and the older patient group (> 60 years) (Figure 2).

Table. Descriptive analysis of mean daily cardiovascular-related hospitalizations. Western São Paulo state, Brazil, $2009-2012$.

\begin{tabular}{|c|c|c|c|c|c|c|c|}
\hline \multirow{2}{*}{ Variable } & \multirow{2}{*}{ Mean } & \multirow{2}{*}{ SD } & \multirow{2}{*}{ Minimum } & \multirow{2}{*}{ Maximum } & \multicolumn{3}{|c|}{ Percentiles } \\
\hline & & & & & 25th & 50th & 75th \\
\hline Total CVD hospital admissions & 4.4 & 2.5 & 0 & 16.0 & 3 & 4 & 6 \\
\hline CVD hospital admissions for people aged $20-60$ years & 1.10 & 1.7 & 0 & 12.0 & 1 & 2 & 3 \\
\hline CVD hospital admissions for people aged $>60$ years & 2.4 & 1.8 & 0 & 12.0 & 1 & 2 & 3 \\
\hline \multicolumn{8}{|l|}{ Pollutants } \\
\hline $\mathrm{PM}_{10}$ & 18.9 & 13.9 & 0 & 101.3 & 9.41 & 15.6 & 26.2 \\
\hline $\mathrm{NO}_{2}$ & 40.7 & 27.9 & 0 & 146.0 & 21.0 & 37.0 & 58.0 \\
\hline \multicolumn{8}{|l|}{ Meteorological variable } \\
\hline Minimum temperature $\left({ }^{\circ} \mathrm{C}\right)$ & 18.8 & 4.5 & 0 & 27.8 & 17.2 & 19.3 & 22.0 \\
\hline Mean temperature $\left({ }^{\circ} \mathrm{C}\right)$ & 23.3 & 3.4 & 8.80 & 32.8 & 21.5 & 23.9 & 25.6 \\
\hline Relative humidity (\%) & 64.9 & 13.8 & 15.00 & 98.5 & 55.5 & 65.5 & 75.0 \\
\hline Wind speed $(\mathrm{m} / \mathrm{s})$ & 1.6 & 0.6 & 0.20 & 3.8 & 1.2 & 1.6 & 2.1 \\
\hline Wind direction $\left({ }^{\circ}\right)$ & 132.4 & 49.3 & 10.16 & 318.1 & 97.8 & 119.3 & 159.0 \\
\hline Precipitation (mbar) & 1.3 & 6.2 & 0 & 110.8 & 0 & 0 & 0.2 \\
\hline
\end{tabular}

CVD: cardiovascular disease; PM: particulate matter; $\mathrm{NO}_{2}$ : nitrogen dioxide

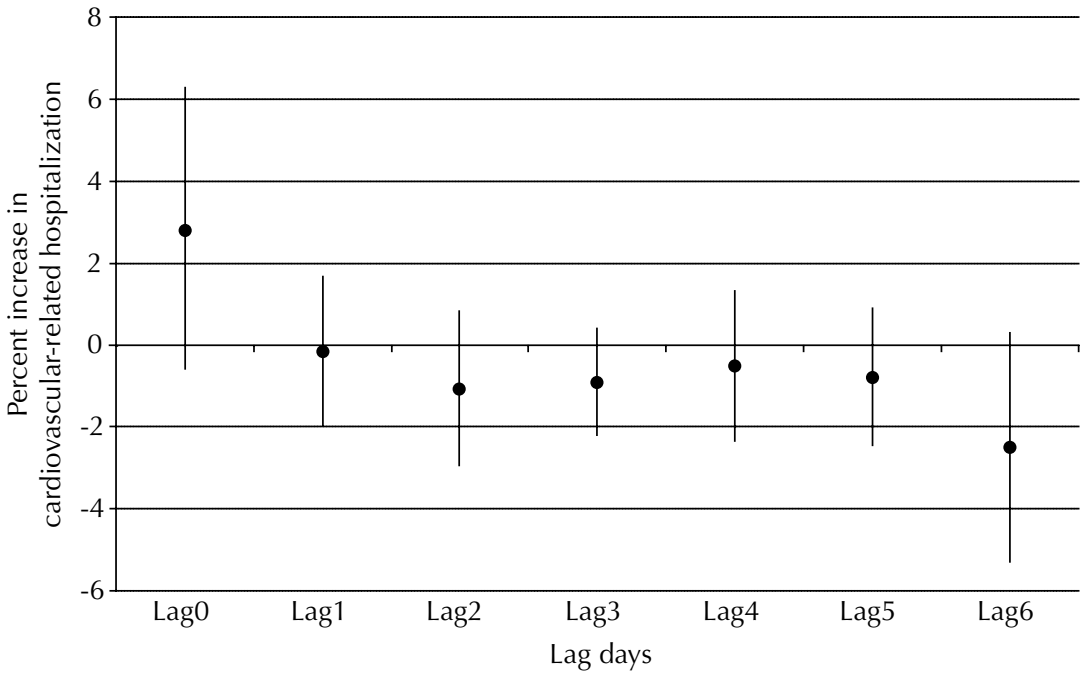

Lag: days of exposure; lag0: same day; lag1-6: one to six days after exposure.

Figure 1. Relationship between percent increase $(95 \% \mathrm{Cl})$ in cardiovascular-related hospitalizations and PM $_{10}$ exposure. Western São Paulo state, Brazil, 2009-2012. 


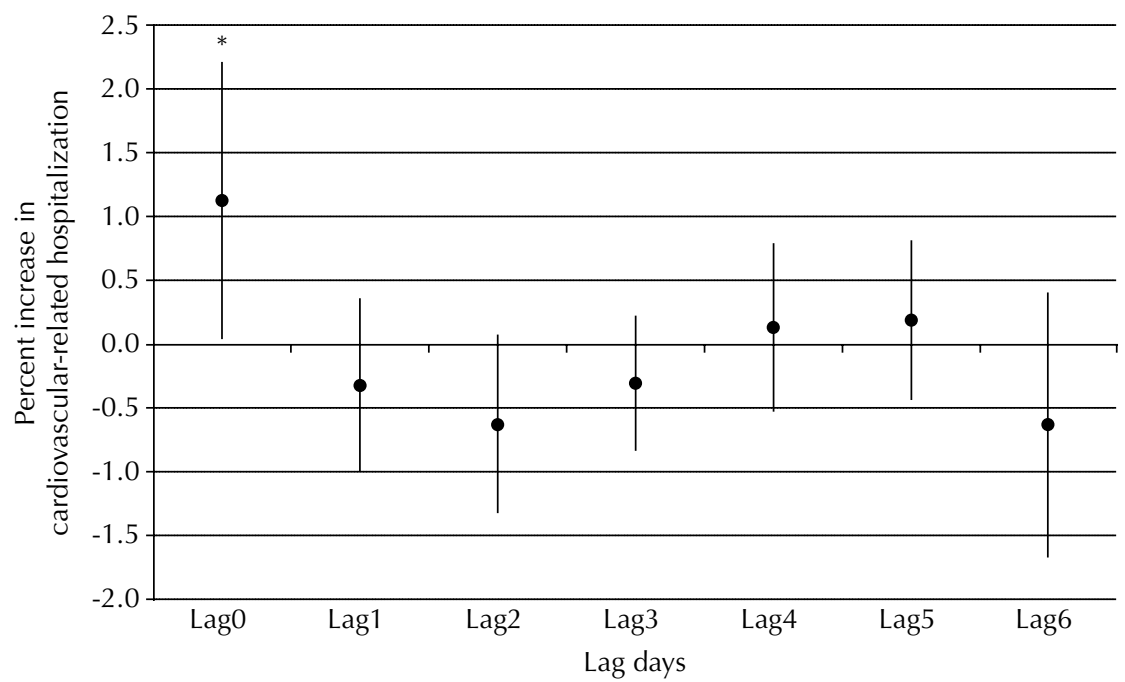

Lag: days of exposure; lag0: same day; lag1-6: one to six days after exposure.

* $\mathrm{p}<0.05$

Figure 2. Lag days between percent increase $(95 \% \mathrm{Cl})$ in cardiovascular-related hospitalizations and $\mathrm{NO}_{2}$ exposure. Western São Paulo state, Brazil, 2009-2012.

\section{DISCUSSION}

This study is the first of its kind to show that indirect exposure to excessive $\mathrm{NO}_{2}$ air pollution levels is related to same-day hospitalizations due to cardiovascular diseases across all adult age groups. The increased risk of hospitalization is small, but statistically significant, and does not persist in the week following exposure. Further data are required to confirm whether similar findings exist in people residing more locally to cities of plantation burning. These findings should inform public health policy in regions affected by sugarcane industry.

These issues cannot be assumed to be the same as those of major urban centers such as São Paulo city, since the cause of air pollution is different. In such cities, the heavy traffic influx predisposes to prolonged exposure of fossil fuels related to traffic movement in and out of town.

This vehicular-related air pollution exposure poses direct risks to the health of local residents, and, in São Paulo, is already known to be associated with hospitalizations due to cardiovascular disease in adult males ${ }^{17}$.

The adverse effects of sugarcane burning in Brazil have been previously reported. In a study from the city of Araraquara, Arbex et al..$^{1}$ found a positive relationship $(\mathrm{r}=0.238, \mathrm{p}<0.001)$ between daily variation in relatively low concentrations of Total Suspended Particulate (TSP) generated after the period of sugarcane burning and daily hospitalizations due to hypertension. This relationship was significant even when no sugarcane burning took place. In contrast to the findings of the present study, however, the study observed the effect to be sustained from the first day after TSP rise to the third day after exposure (i.e., a maintained effect) ${ }^{1}$.

Data from other regions of São Paulo state further support the main study findings. A study from São Paulo city ${ }^{16}$ showed a positive relationship between exposure to excessive air pollution $\left(\mathrm{CO}, \mathrm{PM}_{10}\right.$, ozone $\left.\left[\mathrm{O}_{3}\right], \mathrm{NO}_{2}, \mathrm{SO}_{2}\right)$ and same-day hospitalizations related to cardiovascular disease among older adults. For hospitalizations due to congestive heart failure, the mean risk increase was 3.17\% (95\%CI 2.09-4.25), while for cardiovascular-related diseases this was $0.89 \%(95 \% \mathrm{CI} 0.18-1.61)$. These effects were predominantly acute (i.e., hospitalization on the same day of air pollution exposure) and occurred mostly in females ${ }^{17}$. Increased susceptibility of females to air pollution (excessive $\mathrm{NO}_{2}$ ) has also been reported in the United Kingdom ${ }^{15}$, suggesting that some negative health risks may be greater in specific population sub-groups than the general population - an important consideration 
for public health policy makers. Findings from Southwest São Paulo corroborate findings from the Brazilian city Santo André, where a significant rise in hospitalizations of older adults due to congestive heart failure has also been observed following $\mathrm{PM}_{10}$ exposure $(\text { mean increase } 3.8 \% \text { [95\% CI 0.4-7.2] })^{16}$.

The precise rationale to explain the findings of our study was not explicitly investigated. However, data from studies on this Brazilian region show a similarity with our study. Chiarelli et al. ${ }^{6}$ found a small, but significant positive association between air pollutant exposure $\left(\mathrm{PM}_{10}\right.$ and $\left.\mathrm{O}_{3}\right)$ and increased arterial blood pressure (mean increase $2.53 \mathrm{mmHg}$ [95\%CI 1.25-3.80])7. Importantly, the effect due to $\mathrm{O}_{3}$ exposure was rapid, occurring between two and four hours after exposure. Ozone levels continued to rise to an increase of $49.0 \mu \mathrm{g} / \mathrm{m}^{3}$ by five hours, while the effect of $\mathrm{PM}_{10}$ remained unchanged during three hours (lag $3 \mathrm{~h}$ ). This suggests that the observed increases in cardiovascular-related hospitalizations may be caused by or at least mediated by direct, acute haemodynamic responses following environmental exposure. Other factors, however, may also interact with this process, and clarification of the precise mechanism underpinning this relationship is important.

Interesting data that further our understanding of this relationship recently emerged from Cubatão, a city $40 \mathrm{~km}$ from São Paulo city. Nardocci et al. ${ }^{17}$ investigated the impact of air pollution $\left(\mathrm{PM}_{10}, \mathrm{O}_{3}, \mathrm{NO}_{2}, \mathrm{SO}_{2}\right)$ and meteorological variables upon hospitalizations due to cardiovascular and respiratory diseases. A robust relationship between exposure and hospitalizations was observed not only for adults (> 39 years) with cardiovascular disease, but also those with respiratory disease, suggesting that effects are strongly related to underlying respiratory pathology. This negative health outcome, however, occurred despite yearly average $\mathrm{PM}_{10}$ levels in this urban area being lower than those of São Paulo city at the time of the study and within the recommended air quality test of $50 \mu \mathrm{g} / \mathrm{m}^{3}$ established by Conselho Nacional do Meio Ambiente (CONAMA - National Environment Council) 6 . Similar observations of negative health outcomes associated with acceptable air pollution levels have been observed elsewhere, with individuals who have more prolonged exposure times identified as a subgroup susceptible to heightened risk ${ }^{13}$. This potentially important factor was unexplored in the present study; however, no relationship suggestive of susceptibility to more prolonged air pollution exposure time was observed in our data. Therefore, it may be reasonable to consider our findings a conservative underestimation of the true health impact of air pollutant exposure in Western São Paulo. Further studies appear indicated to elucidate these precise mechanisms to aid our understanding of this important issue.

The present study findings highlight the negative impact of air pollution on acute cardiovascular health in the developing region of Western São Paulo. The predominance of sugarcane industry with its associated plantation burning and increased $\mathrm{NO}_{2}$ levels makes this an important region for further investigation to unravel the precise mechanisms underpinning this relationship. Such information is crucial to optimise the health of residents living both locally and afar. In addition to existing evidences, these findings reinforce the necessity for banning sugar cane burning.

\section{REFERENCES}

1. Arbex MA, Saldiva PHN, Pereira LAA, Braga ALF. Impact of outdoor biomass air pollution on hypertension hospital admissions. J Epidemiol Community Health. 2010;64(7):573-9. https://doi.org/10.1136/jech.2009.094342

2. Arbex MA, Pereira LAA, Carvalho-Oliveira R, Saldiva PHN, Braga ALF. The effect of air pollution on pneumonia-related emergency department visits in a region of extensive sugar cane plantations: a 30-month time-series study. J Epidemiol Comm Health. 2014;68(7):669-74. https://doi.org/10.1136/jech-2013-203709

3. Braga ALF, Pereira LAA, Procópio M, André PA, Saldiva PHN. Associação entre poluição atmosférica e doenças respiratórias e cardiovasculares na cidade de Itabira, Minas Gerais, Brasil. Cad Saude Publica. 2007;23(supl 4):570-8. https://doi.org/10.1590/S0102-311X2007001600017 
4. Cesaroni G, Badaloni C, Gariazzo C, Stafoggia M, Sozzi R, Davoli M et al. Long-term exposure to urban air pollution and mortality in a cohort of more than a million adults in Rome. Environ Health Perspect. 2013;121(3):324-31. https://doi.org/10.1289/ehp.1205862

5. César ACG, Carvalho JÁ, Nascimento LFC. Exposição a poluentes atmosféricos e as doenças respiratórias e cardiovasculares em Piracicaba, SP. In: The 4th International Congress on University-Industry Cooperation; 5-7 dez 2012; Taubaté, Brasil. Taubaté (SP): Universidade de Taubaté; 2012.

6. Chiarelli PS, Pereira LAA, Saldiva PHN, Ferreira Filho C, Garcia MLB, Braga ALF et al. The association between air pollution and blood pressure in traffic controllers in Santo André, São Paulo, Brazil. Environ Res. 2011;111(5):650-5. https://doi.org/10.1016/j.envres.2011.04.007

7. Evo CPR, Ulrych BK, Takegawa B, Soares G, Nogueira G, Oliveira LO et al. Poluição do ar e internação por insuficiência cardíaca congestiva em idosos no município de Santo André. Arq Bras Cienc Saude. 2011;36(1):6-9. https://doi.org/10.7322/abcs.v36i1.68

8. Ferreira-Ceccato AD, Ramos EMC, Carvalho Junior LCS, Xavier RF, Teixeira MFS, Raymundo-Pereira PA et al. Short terms effects of air pollution from biomass burning in mucociliary clearance of Brazilian sugarcane cutters. Resp Med. 2011;105(11):1766-8. https://doi.org/10.1016/j.rmed.2011.08.003

9. Habermann M, Medeiros APP, Gouveia N. Tráfego veicular como método de avaliação da exposição à poluição atmosférica nas grandes metrópoles. Rev Bras Epidemiol. 2011;14(1):120-30. https://doi.org/10.1590/S1415-790X2011000100011

10. Habermann M, Gouveia N. Tráfego veicular e mortalidade por doenças do aparelho circulatório em homens adultos. Rev Saude Publica. 2012;46:(1):26-33. https://doi.org/10.1590/S0034-89102011005000079

11. Heinrich J, Thiering E, Rzehak P, Krämer U, Hochadel M, Rauchfuss KM et al. Long-term exposure to $\mathrm{NO}_{2}$ and $\mathrm{PM}_{10}$ and all-cause and cause-specific mortality in a prospective cohort of women. Occup Environ Med. 2013;70(3):179-86. https://doi.org/10.1136/oemed-2012-100876

12. Ito MS, Ramos EMC, Pestana PRS, Ceccato ADF, Carvalho-Junior LCS, Tommaselli JTG et al. Hospitalizações por doenças respiratórias associados à exposição de metais Tóxicos no material particulado e nível de temperatura em Presidente Prudente, SP, Brasil. Colloquium Vitae. 2013;5(2):110-8. https://doi.org/10.5747/cv.2013.v005.n2.v081

13. Jasinski R, Pereira LAA, Braga ALF. Poluição atmosférica e internações hospitalares por doenças respiratórias em crianças e adolescentes em Cubatão, São Paulo, Brasil, entre 1997 e 2004. Cad Saude Publica. 2011;27(11):2242-52. https://doi.org/10.1590/S0102-311X2011001100017

14. Jevtić M, Dragić N, Dijelović S, Popović M. Cardiovascular diseases and air pollution in Novi Sad, Serbia. Int J Occup Med Environ Health. 2014;27(2):153-64. https://doi.org/10.2478/s13382-014-0239-y

15. Martins LC, Pereira LAA, Lin CA, Santos UP, Prioli G, Luiz OC et al. The effects of air pollution on cardiovascular diseases: lag structures. Rev Saude Publica. 2006;40(4):677-83. https://doi.org/10.1590/S0034-89102006000500018

16. Milojevic A, Wilkinson P, Armstrong B, Bhaskaran K, Smeeth L, Hajat S. Short-term effects of air pollution on a range of cardiovascular events in England and Wales: case-crossover analysis of the MINAP database, hospital admissions and mortality. Heart. 2014;100(14):1093-8. https://doi.org/10.1136/heartjnl-2013-304963

17. Nardocci AC, Umbelino de Freitas C, Ponce de Leon ACM, Junger WL, Gouveia NC. Poluição do ar e doenças respiratórias e cardiovasculares: estudo de séries temporais em Cubatão, São Paulo, Brasil. Cad Saude Publica. 2013;29(9):1867-76. https://doi.org/10.1590/S0102-311X2013001300025

18. Negrete BR, Rosa CC, Ikeuti DH, Delena PJ, Borba TM, Braga ALF. Poluição atmosférica e internações por insuficiência cardíaca congestiva em adultos e idosos em Santo André (SP). Arq Bras Cienc Saude. 2010;35(3):208-12.

19. Nogueira JB. Poluição atmosférica e doenças cardiovasculares. Rev Portug Cardiol. 2009;28(6):715-33.

20. Silva EN, Ribeiro H. Impact of urban atmospheric environment on hospital admissions in the elderly. Rev Saude Publica. 2012;46(4):694-701. https://doi.org/10.1590/S0034-89102012005000052

21. Stieb DM, Szyszkowicz1 M, Rowe BH, Leech JA. Air pollution and emergency department visits for cardiac and respiratory conditions: a multi-city time-series analysis. Environ Health. 2009;8(1):25. https://doi.org/10.1186/1476-069X-8-25 
22. Wong CM, Vichit-Vadakan N, Kan H, Qian Z. Public Health and Air Pollution in Asia (PAPA): a multicity study of short-term effects of air pollution on mortality. Environ Health Perspect. 2008;116(1):1195-202. https://doi.org/10.1289/ehp.11257

23. Zanobetti A, Schwartz J. Air pollution and emergency admissions in Boston, MA. J Epidemiol Community Health. 2006;60(10):890-5. https://doi.org/10.1136/jech.2005.039834

24. Zhang P, Dong G, Sun B, Zhang L, Chen X, Ma N et al. Long-term exposure to ambient air pollution and mortality due to cardiovascular disease and cerebrovascular disease in Shenyang, China. PLoS One. 2011;6(6):e20827. https://doi.org/10.1371/journal.pone.0020827

Authors' Contribution: Contribution to design and planning of the suty, analysis and data interpretation: PRSP, DR; ALFB. Elaboration and review of the manuscript: PRSP, DR; ALFB; EMCR; AFO. Approval of the final version and critical review of the manuscript: PRSP, DR; ALFB; CRO; ADFC.

Conflict of Interest: The authors declare no conflict of interest. 